\title{
PERAN AKUNTABILITAS DAN PENGETAHUAN TERHADAP KUALITAS HASIL AUDIT DENGAN MODERASI SIKAP MENTAL AUDITOR
}

\author{
Rd. Susana Suspayati, Syahril Djaddang, dan Darmansyah \\ Magister Akuntansi Universitas Pancasila \\ Email: qiu zu@yahoo.co.id
}

ARTICLE INFO

Article History

Received 1 December 2018

Revised 15 December 2018

Accepted 10 January 2019

\section{JEL Classification}

G30, M42

Keywords:

Quality of Audit Result,

Accountability,

Knowledge, and

Mental Attitude of Auditor

\section{ABSTRACT}

In order to guarantee quality audit results, each auditor explains the Auditing Standards. This study aims to determine the effect of accountability and knowledge on the quality of audit results with auditor's mental attitude as moderation. In this research survey method was used. The variables studied were independent variables including accountability, knowledge, and dependent variable was the quality of audit results, with the auditor's mental attitude as moderation variable. The samples were 80 auditors from KAP Kanaka Puradiredja, Suhartono, KAP Albert Silalahi \& Rekan, and KAP S. Mannan, Ardiansyah \& Rekan. The data was collected by questionnaire to measure perception of the auditor related to the variables tested. The technique of processing and data analysis was using Warp PLS 6.0 with Equation Model of Goodness of Fit Model. The results of this research: (1) there was no influence on accountability variable to audit result quality, and there was no accounting moderator to audit result quality. (2) There was a positive significant influence on the knowledge variable on the quality of the audit result (3). There was a significant positive effect on the auditor's mental attitude variable on the quality of audit results.

\section{PENDAHULUAN}

Profesi akuntan publik merupakan profesi kepercayaan masyarakat. Dari profesi akuntan publik, masyarakat mengharapkan penilaian yang bebas dan tidak memihak terhadap informasi yang disajikan oleh manajemen perusahaan. Dalam laporan keuangan profesi akuntan publik bertanggungjawab untuk menaikkan tingkat keandalan laporan keuangan perusahaan, sehingga masyarakat memperoleh informasi laporan keuangan yang andal sebagai dasar pengambilan keputusan Arisanti, dkk (2013).
Berbagai temuan terhadap laporan keuangan yang dihasilkan akuntan publik pada umumnya telah menimbulkan persepsi negatif pada masyarakat dan pengguna jasa layanan akuntan publik yang menyebabkan menurunnya kualitas hasil audit. Hal ini dapat ditemukan dalam berbagai kasus yang terjadi di Indonesia diantaranya, yaitu kasus PT Telkom Tbk yang melibatkan KAP Eddy Pianto dan KAP Haryanto. KAP Eddy Pianto tidak dapat menyelesaikan laporan audit sesuai waktu yang ditentukan dan KAP Eddy Pianto tidak dapat memberikan opini audit atas proses audit yang dilakukan. Selain itu ada 
kasus PT Easman Christensen yang melibatkan KAP Siddharta Siddharta dan Harsono, yaitu KAP tersebut menyogok aparat pajak di Indonesia dengan menerbitkan faktur pajak palsu untuk biaya jasa audit yang harus dibayar PT Easman Christensen. Serta kasus PT Great River International Tbk yang melibatkan KAP Justinus Aditya Siddharta yaitu terbukti telah melakukan pelanggaran terhadap SPAP berkaitan dengan Laporan Audit atas Laporan Keuangan Konsolidasi PT Great River International Tbk tahun 2003 dengan terjadinya gagal bayar obligasi yang diterbitkan perusahaan. Dari pelanggaran yang dilakukan Kantor Akuntan Publik diberikan sanksi berupa pembayaran denda, pembekuan izin usaha, hingga pencabutan izin usaha.

Tabel 2. Research Gap Akuntabilitas, Pengetahuan terhadap Kualitas Hasil Audit dengan Moderasi Sikap Mental Auditor

\begin{tabular}{|c|c|c|c|c|c|}
\hline \multirow[t]{2}{*}{ Nama Peneliti } & \multirow{2}{*}{$\begin{array}{l}\text { Akunta } \\
\text { bilitas }\end{array}$} & \multirow{2}{*}{$\begin{array}{l}\text { Peng } \\
\text { etahu } \\
\text { an }\end{array}$} & \multirow{2}{*}{$\begin{array}{l}\text { Sikap } \\
\text { Mental } \\
\text { Auditor }\end{array}$} & \multicolumn{2}{|c|}{ Kualitas Hasil Audit } \\
\hline & & & & Berpengaruh & $\begin{array}{c}\text { Tidak } \\
\text { Berpengaruh }\end{array}$ \\
\hline $\begin{array}{l}\text { Saripudin, Herawaty. N, dan } \\
\text { Rahayu., (2012) }\end{array}$ & $\sqrt{ }$ & & & $\sqrt{ }$ & \\
\hline Mardisar, D. dan Sari, R. N. (2007) & $\sqrt{ }$ & $\sqrt{ }$ & & $\sqrt{ }$ & \\
\hline Ardini, L. (2010) & $\sqrt{ }$ & & & $\mathrm{V}$ & \\
\hline Ichnatesya, Afika Simarmata (2016) & & $\mathrm{V}$ & & $\mathrm{V}$ & \\
\hline DamayantiTesalonika Ruth (2015) & & $\sqrt{ }$ & $\sqrt{ }$ & $\mathrm{V}$ & \\
\hline Hidayat, Sarip. (2015) & $\sqrt{ }$ & & & $\mathrm{V}$ & \\
\hline Febri, Muhammad Haryoto. (2017) & $\sqrt{ }$ & $\sqrt{ }$ & & $\mathrm{V}$ & \\
\hline $\begin{array}{l}\text { Arisanti, Dea., Dwi Fitri Puspa., } \\
\text { Herawati (2013) }\end{array}$ & $\sqrt{ }$ & & & & $\mathrm{v}$ \\
\hline $\begin{array}{l}\text { Kadek, Ayu Prihartini., Luh Gede } \\
\text { Erni Sulindawati., Nyoman Ari Surya } \\
\text { Darmawan(2015) }\end{array}$ & $\sqrt{ }$ & & & & $\sqrt{ }$ \\
\hline $\begin{array}{l}\text { Purnamasari, Dina dan Erna } \\
\text { Hernawati. (2013) }\end{array}$ & & $\sqrt{ }$ & & $\sqrt{ }$ & \\
\hline $\begin{array}{l}\text { Putu, Ni Luh Tri Angga Wandita., } \\
\text { Gede Adi Yuniarta., Nyoman Ari } \\
\text { Surya Darmawan(2014) }\end{array}$ & $\sqrt{ }$ & $\sqrt{ }$ & & $\sqrt{ }$ & \\
\hline $\begin{array}{l}\text { Ali, Muhammad Imron., Tri } \\
\text { Widyastuti., Amilin. (2017) }\end{array}$ & & $\sqrt{ }$ & & $\sqrt{ }$ & \\
\hline $\begin{array}{l}\text { Alim M. Nizarul, Trisni Hapsari dan } \\
\text { Lilik Purwati (2007) }\end{array}$ & & & $\sqrt{ }$ & & $\sqrt{ }$ \\
\hline
\end{tabular}

Sumber : Penelitian terdahulu, diolah 2018

Menurut Hidayat (2015), kualitas hasil audit adalah probabilitas seorang auditor, dapat menemukan dan melaporkan suatu penyelewengan yang terjadi dalam sistem akuntansi klien. Probabilitas penemuan penyelewengan tergantung pada kemampuan teknikal auditor, seperti pengalaman auditor, pendidikan, profesionalisme dan struktur audit perusahaan. Sedangkan probabilitas auditor tersebut melaporkan penyelewengan tersebut tergantung pada independensi dalam melaksanakan tugasnya yang tercermin dalam hasil pemeriksaannya yang dapat diandalkan sesuai dengan standar yang berlaku. Hasil audit pelaksanaan pengelolaan keuangan dikatakan berkualitas jika hasil pemeriksanaan (audit) dapat dipertanggungjawabkan atau akuntabilitas, serta dapat memberikan informasi pembuktian ada tidaknya 
penyimpangan dari standar-standar audit di sektor pemerintahan.

Kualitas dari hasil pekerjaan auditor dapat dipengaruhi oleh rasa kebertanggung jawaban (akuntabilitas) yang dimiliki auditor dalam menyelesaikan pekerjaan audit. Akuntabilitas merupakan dorongan psikologi sosial yang dimiliki seseorang untuk menyelesaikan kewajibannya yang akan dipertanggungjawabkan kepada lingkungannya (Mardisar dan Sari, 2007).

Berdasarkan penelitian Saripudin (2012), menyatakan akuntabilitas sebagai bentuk dorongan psikologi yang membuat seseorang berusaha mempertanggungjawab kan semua tindakan dan keputusan yang diambil kepada lingkungannya. Penelitiannya membuktikan bahwa akuntabilitas mempengaruhi kualitas audit secara berkelanjutan.

Mardisar dan Sari (2007) berpendapat bahwa seseorang dengan akuntabilitas tinggi memiliki keyakinan yang lebih tinggi bahwa pekerjaan mereka akan diperiksa oleh supervisor/manajer/pimpinan dibandingkan dengan seseorang yang memiliki akuntabilitas rendah. Dari penelitian tersebut menunjukkan bahwa ketika kompleksitas tugas yang rendah, akuntabilitas memiliki efek terhadap kualitas hasil audit, akan tetapi pada saat kompleksitas tugas tinggi, akuntabilitas tidak memiliki pengaruh terdapat kualitas hasil kerja auditor. Lebih lanjut, ketika kompleksitas tugas tinggi, interaksi antar akuntabilitas dan pengetahuan memiliki pengaruh yang signifikan terhadap kualitas pekerjaan auditor.

Dalam standar umum dikatakan auditor independen harus melaksanakan tugasnya dengan cermat dan seksama. Jadi kecermatan dan keseksamaan merupakan tanggung jawab setiap auditor. Akuntabilitas (tanggung jawab) yang harus dimiliki auditor, yaitu tanggung jawab kepada klien dan tanggungjawab rekan seprofesi (Ardini, 2010). Dalam penelitian ini, menyatakan bahwa akuntabilitas secara parsial dan bersamaan berpengaruh signifikan positif terhadap kualitas audit. Menurut Putu, dkk (2014), menyatakan bahwa akuntabilitas berpengaruh positif dan signifikan terhadap kualitas hasil kerja auditor. Namun bertentangan dengan penelitian Arisanti, dkk (2013) dan Kadek, dkk (2015), menyatakan bahwa akuntabilitas tidak memiliki pengaruh secara signifikan terhadap kualitas audit.

Pengetahuan diukur dari seberapa tinggi pendidikan seorang auditor karena dengan demikian auditor akan mempunyai banyak pengetahuan (pandangan) mengenai bidang yang digelutinya sehingga dapat mengetahui berbagai masalah secara lebih mendalam, selain itu auditor akan lebih mudah dalam mengikuti perkembangan yang semakin kompleks (Harhinto, 2004).

Menurut penelitian Ichnatesya (2016), pengalaman, pengetahuan, etika, dan motivasi berpengaruh terhadap kualitas audit. Hasil penelitiannya membuktikan bahwa adanya pengaruh yang signifikan antara pengetahuan, etika, dan motivasi terhadap kualitas audit. Sedangkan pengalaman tidak berpengaruh terhadap kualitas audit.

Menurut penelitian Ali, dkk. (2017), menyatakan bahwa pengetahuan audit berpengaruh signifikan terhadap kualitas audit. Didukung pula oleh penelitian Purnamasari (2013), yang menyatakan bahwa pengetahuan berpengaruh terhadap kualitas audit. Serta penelitian menurut Ichnatesya (2016), Febri (2017), dan Putu, dkk. (2014), yang menyatakan bahwa pengetahuan berpengaruh terhadap kualitas audit.

Moderasi sikap mental pada dasarnya merupakan suatu sistem (input, proses, output) dan seperangkat peraturan yang mengatur hubungan antara berbagai pihak yang berkepentingan (stakeholders) terutama dalam menghadapi masalah yang sering di hadapi para auditor untuk menghasilkan kualitas kerjanya. Menurut penelitian Damayanti (2015), sikap auditor berpengaruh terhadap kualitas hasil audit. Hasil penelitiannya membuktikan bahwa adanya 
pengaruh yang signifikan antara sikap auditor terhadap kualitas hasil audit. Namun bertentangan dengan penelitian ini, Nizarul, dkk. (2007) menyatakan bahwa sikap auditor tidak berpengaruh signifikan terhadap kualitas audit.

Ketika kompleksitas tugas yang rendah, akuntabilitas memiliki efek terhadap kualitas hasil audit, akan tetapi pada saat kompleksitas tugas tinggi, akuntabilitas tidak memiliki pengaruh terdapat kualitas hasil auditor. Lebih lanjut, ketika kompleksitas tugas tinggi, interaksi antar akuntabilitas dan pengetahuan memiliki pengaruh yang signifikan terhadap kualitas pekerjaan auditor dan didorong oleh sikap mental auditor yang tinggi dapat berpengaruh terhadap kualitas hasil auditor.

Adapun identifikasi masalah dalam penelitian ini adalah masih kurangnya kompetensi auditor dikarenakan kurangnya pendidikan dan kualitas hasil audit, pelatihan audit, baik internal maupun eksternal perusahaan. Masih terdapat auditor yang kurang berpengalaman dalam bidang pemeriksaan dan pengawasan. Sikap mental dan kepribadian seorang auditor yang dapat mempengaruhi kualitas hasil audit. Terdapat keraguan oleh pengguna laporan audit karena menurunnya kualitas hasil audit yang disebabkan menurunnya profesionalisme. Terdapat keraguan oleh pengguna laporan audit karena menurunnya kualitas hasil audit yang disebabkan menurunnya independensi.

Adapun batasan masalah dalam penelitian ini yaitu pada KAP Kanaka Puradiredja, Suhartono, KAP Albert Silalahi \& Rekan, dan KAP S. Mannan, serta Ardiansyah \& Rekan yang terdapat di Jakarta Selatan.

\section{TINJAUAN PUSTAKA DAN PENGEMBANGAN HIPOTESIS}

\section{Stakeholder Theory}

Stakeholders merupakan teori yang menyatakan bahwa perusahaan akan memilih secara sukarela mengungkapkan informasi tentang kerja lingkungan, sosial dan intelektual perusahaan melebihi permintaan wajibnya untuk memenuhi keinginan stakeholders. (Ghozali dan Chariri, 2007).

Stakeholder theory menyatakan bahwa perusahaan bukanlah entitas yang beroperasi untuk kepentingannya sendiri namun harus memberikan manfaat bagi stakeholdernya (pemegang saham, konsumen, supplier, pemerintah, masyarakat, kreditor, analisis), keberadaan suatu perusahaan sangat dipengaruhi oleh dukungan yang diberikan oleh stakeholder kepada perusahaan tersebut (Ghozali, 2014).

\section{Stewardship Theory}

Teori Stewardship menggambarkan bahwa berdasarkan asumsi filosofis mengenai sifat manusia bahwa manusia dapat dipercaya, bertanggung jawab, dan manusia merupakan individu yang berintegrasi menurut Murwaningsari (2009). Teori stewardship manajer akan berperilaku sesuai kepentingan bersama. Ketika kepentingan steward dan pemilik tidak sama, steward akan berusaha bekerja sama daripada menentangnya, karena steward merasa kepentingan bersama dan berperilaku sesuai dengan perilaku pemilik merupakan pertimbangan yang rasional karena steward lebih melihat pada usaha untuk mencapai tujuan organisasi.

\section{Disonansi Kognitif}

Sarwono (2009) mendefinisikan disonansi kognitif sebagai keadaan tidak nyaman akibat adanya ketidaksesuaian antara dua sikap atau lebih serta antara sikap dan tingkah laku. Festinger (1957) berpendapat bahwa disonansi terjadi apabila terdapat hubungan yang bertolak belakang, yang diakibatkan oleh penyangkalan dari satu elemen kognitif terhadap elemen lain, antara elemen-elemen kognitif dalam diri individu. Bila terjadi disonansi, ada sesuatu yang harus dilepas, atau ada ketidaksesuaian antara suatu keyakinan dengan keyakinan-keyakinan atau sikap yang penting. Bersikeras mempertahankan kedua-duanya, akan terasa sangat menyiksa. 


\section{Kualitas Hasil Audit}

Menurut Febri (2017), kualitas dari hasil pekerjaan auditor dapat di pengaruhi oleh rasa tanggung jawab (akuntabilitas) yang dimiliki auditor dalam menyelesaikan pekerjaan audit. Akuntabilitas merupakan dorongan psikologi sosial yang dimiliki seseorang untuk menyelesaikan kewajibannya yang akan dipertanggungjawabkan kepada lingkungannya. Tingkat akuntabilitas individu dalam melakukan suatu pekerjaan sangat menentukan bagaimana suatu informasi diproses. Hasil dari informasi yang diproses, akan dapat mempengaruhi respon, keputusan maupun tindakan yang akan diambil. Semakin besar tingkat akuntabilitas seorang auditor maka semakin tinggi pula kualitas hasil kerja auditor.

\section{Akuntabilitas}

Mardisar dan Sari (2007), menyatakan seseorang dengan akuntabilitas tinggi memiliki keyakinan yang lebih tinggi bahwa pekerjaan mereka akan diperiksa oleh supervisor/manajer/pimpinan dibandingkan dengan seseorang yang memiliki akuntabilitas rendah. Dalam standar umum dikatakan auditor independen harus melaksanakan tugasnya dengan cermat dan seksama. Jadi kecermatan dan keseksamaan merupakan tanggung jawab setiap auditor. Akuntabilitas (tanggung jawab) yang harus dimiliki auditor, yaitu tanggung jawab kepada klien dan tanggungjawab rekan seprofesi (Ardini, 2010).

\section{Pengetahuan (Knowledge)}

Pengetahuan diukur dari seberapa tinggi pendidikan seorang auditor karena dengan demikian auditor akan mempunyai banyak pengetahuan (pandangan) mengenai bidang yang digelutinya sehingga dapat mengetahui berbagai masalah secara lebih mendalam. Selain itu auditor akan lebih mudah dalam mengikuti perkembangan yang semakin kompleks (Harhinto, 2004).

\section{Sikap Mental Auditor}

Winardi (2009) menyatakan sikap adalah determinan perilaku, karena mereka berkaitan dengan persepsi, kepribadian, dan motivasi. Sebuah sikap merupakan suatu keadaan siap mental, yang dipelajari diorganisasi menurut pengalaman, dan yang menyebabkan timbulnya pengaruh khusus atas reaksi seseorang terhadap orang-orang, objek-objek, dan situasi-situasi dengan siapa ia berhubungan.

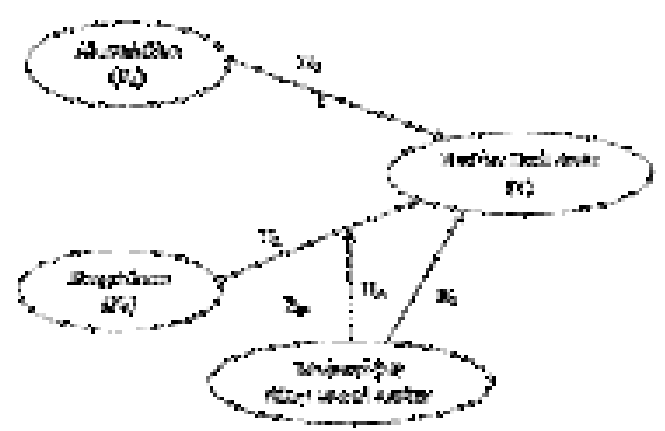

Gambar 1. Model Penelitian. Pengaruh Akuntabilitas dan Pengetahuan Terhadap Kualitas Audit dengan Moderasi Sikap Mental Auditor

Dalam hal ini:

$\mathrm{X}_{1} \quad$ : Akuntabilitas

$\mathrm{X}_{2} \quad$ : Pengetahuan

Y : Kualitas Audit

M : Sikap Mental Auditor

\section{Kerangka Pemikiran dan Pengembangan Hipotesis \\ Hubungan Konseptual antara Akuntabilitas dengan Kualitas Hasil Audit}

BPKP (2007) menyatakan bahwa akuntabilitas berarti sebagai perwujudan pertanggungjawaban seseorang atau unit organisasi, dalam mengelola sumber daya yang telah diberikan dan dikuasai, dalam rangka pencapaian tujuan, melalui suatu media berupa laporan akuntabilitas kinerja secara periodik. 
Akuntabilitas (tanggung jawab) yang harus dimiliki auditor, yaitu tanggung jawab kepada klien dan tanggungjawab rekan seprofesi (Ardini, 2010). Dalam penelitian ini, menyatakan bahwa akuntabilitas secara parsial dan bersamaan berpengaruh signifikan positif terhadap kualitas audit. Menurut Putu, dkk (2014), menyatakan bahwa akuntabilitas berpengaruh positif dan signifikan terhadap kualitas hasil kerja auditor.

Namun bertentangan dengan penelitian Arisanti, dkk (2013) dan Kadek, dkk (2015), menyatakan bahwa akuntabilitas tidak memiliki pengaruh secara signifikan terhadap kualitas audit.

Dengan adanya hasil penelitian tersebut, penelitian ini mencoba menguji kembali hubungan antara akuntabilitas terhadap kualitas hasil audit dengan moderasi sikap mental pada hipotesis berikut:

$H_{1}$ : Terdapat pengaruh akuntabilitas terhadap kualitas hasil audit.

$\mathrm{H}_{1 \mathrm{a}}$ : Terdapat pengaruh akuntabilitas terhadap kualitas hasil audit dengan moderasi sikap mental auditor.

Jadi dapat dikatakan jika akuntabilitas tinggi maka kualitas hasil audit akan tinggi, sebaliknya jika akuntabilitas rendah maka kualitas hasil audit akan rendah.

\section{Hubungan Konseptual antara Pengetahuan dengan Kualitas Hasil Audit}

Elfarini (2007) menyatakan bahwa pengetahuan memiliki pengaruh signifikan terhadap kualitas audit. Adapun SPAP 2001 tentang standar umum, menjelaskan bahwa dalam melakukan audit, auditor harus memiliki keahlian dan struktur pengetahuan yang cukup.

Menurut penelitian Ali, dkk (2017), pengetahuan audit berpengaruh signifikan terhadap kualitas audit. Didukung pula oleh penelitian Purnamasari (2013), yang menyatakan hal yang sama begitu juga
Ichnatesya (2016), Febri (2017), dan Putu, dkk (2014).

Berdasarkan penelitian di atas, penulis mencoba memprediksi hubungan pengetahuan terhadap kualitas hasil audit dengan moderasi sikap mental pada hipotesis berikut:

$\mathrm{H}_{2}$ : Terdapat pengaruh pengetahuan terhadap kualitas hasil audit.

$\mathrm{H}_{2 \mathrm{a}}$ : Terdapat pengaruh pengetahuan terhadap kualitas hasil audit dengan moderasi sikap mental auditor.

Jadi dapat dikatakan jika pengetahuan yang dimiliki auditor semakin tinggi maka kualitas hasil audit akan lebih baik. Sebaliknya jika pengetahuan yang dimiliki auditor rendah makan kualitas hasil audit nya juga akan menurun.

\section{Hubungan Konseptual antara Sikap Mental} Auditor dengan Kualitas Hasil Audit

Winardi (2009) menyatakan sikap adalah determinan perilaku, karena mereka berkaitan dengan persepsi, kepribadian, dan motivasi. Sebuah sikap merupakan suatu keadaan siap mental, yang dipelajari, diorganisasi menurut pengalaman, dan yang menyebabkan timbulnya pengaruh khusus atas reaksi seseorang terhadap orang-orang, objek-objek, dan situasi-situasi dengan siapa ia berhubungan.

Menurut penelitian Damayanti (2015), mengenai pengaruh sikap auditor terhadap kualitas hasil audit. Hasilnya membuktikan bahwa adanya pengaruh yang signifikan antara sikap auditor terhadap kualitas hasil audit. Namun bertentangan dengan penelitian Nizarul, dkk (2007) yang menyatakan bahwa sikap auditor tidak berpengaruh signifikan terhadap kualitas audit.

Berdasarkan penelitian di atas, penulis mencoba memprediksi hubungan sikap mental auditor terhadap kualitas hasil audit pada hipotesis berikut:

$\mathrm{H}_{3}$ : Terdapat pengaruh sikap mental auditor terhadap kualitas hasil audit. 
Jadi dapat dikatakan jika sikap mental auditor yang dimiliki semakin baik maka kualitas hasil audit akan lebih baik. Sebaliknya jika sikap mental auditor yang dimiliki buruk makan kualitas hasil audit nya juga akan menurun.

\section{METODOLOGI PENELITIAN Jenis Penelitian}

Tipe penelitian digunakan adalah explanatory research. Janis penelitian ini bertujuan untuk menjelaskan hubungan kasual antara variable-variabel penelitian dan menguji hipotesis yang dirumuskan.

Populasi dan Teknik Penarikan Sampel Populasi dalam penelitian ini adalah auditor yang bekerja di KAP Kanaka Puradiredja, Suhartono, KAP Albert Silalahi \& Rekan, dan KAP S. Mannan, Ardiansyah \& Rekan sejumlah 400 orang, dengan rincian sesuai dengan jenjang jabatan yaitu Partner (18 orang), Senior Manager (8 orang), Manager (17 orang), Asisten Manager (36 orang), Senior 2 (49 orang), Senior 1 (58 orang), Asisten Senior (82 orang), Junior Audit (132 orang). Kantor Akuntan Publik Kanaka Puradiredja, Suhartono, KAP Albert Silalahi \& Rekan, dan KAP S. Mannan, Ardiansyah \& Rekan dipilih sebagai lokasi penelitian karena secara geografis daerahnya mudah dijangkau, sehingga bisa memperoleh jumlah responden yang lebih banyak dan kekuatan generalisasinya lebih tinggi.

\section{Operasionalisasi Variabel}

Tabel 3. Operasionalisasi Variabel

\begin{tabular}{|c|c|c|c|c|c|}
\hline No & Variabel & Konsep Variabel & Sub-Variabel & $\begin{array}{c}\text { No. } \\
\text { Pertanyaan }\end{array}$ & $\begin{array}{l}\text { Skala } \\
\text { Data }\end{array}$ \\
\hline \multirow[t]{3}{*}{1} & \multirow[t]{3}{*}{ Akuntabilitas } & \multirow{3}{*}{$\begin{array}{l}\text { Besarnya dorongan } \\
\text { psikologis seorang auditor } \\
\text { untuk berusaha } \\
\text { mempertanggungjawabka } \\
\text { n semua } \\
\text { tindakan/pekerjaannya } \\
\text { dan keputusan yang } \\
\text { diambil kepada } \\
\text { lingkungan/masyarakat }\end{array}$} & Motivasi & 1 & interval \\
\hline & & & $\begin{array}{l}\text { Pengabdian } \\
\text { pada profesi }\end{array}$ & $2-4$ & interval \\
\hline & & & $\begin{array}{l}\text { Kewajiban } \\
\text { Sosial }\end{array}$ & 5 & interval \\
\hline \multirow[t]{3}{*}{2} & \multirow[t]{3}{*}{ Pengetahuan } & \multirow{3}{*}{$\begin{array}{l}\text { Pengetahuan akan } \\
\text { mempengaruhi keahlian } \\
\text { audit yang pada } \\
\text { gilirannya akan } \\
\text { menentukan kualitas } \\
\text { audit. }\end{array}$} & $\begin{array}{l}\text { Keahlian dan } \\
\text { keterampilan } \\
\text { kerja }\end{array}$ & $6-8$ & interval \\
\hline & & & $\begin{array}{l}\text { Pendidikan } \\
\text { Formal }\end{array}$ & $9-10$ & interval \\
\hline & & & $\begin{array}{l}\text { Pelatihan } \\
\text { Auditor }\end{array}$ & $11-12$ & interval \\
\hline \multirow[t]{3}{*}{3} & \multirow[t]{3}{*}{$\begin{array}{c}\text { Kualitas Hasil } \\
\text { Audit }\end{array}$} & \multirow{3}{*}{$\begin{array}{l}\text { Proses Pelaksanaan audit, } \\
\text { mulai dari perencanaan } \\
\text { sampai dengan } \\
\text { pelaporannya yang } \\
\text { berpedoman pada standar } \\
\text { audit dank ode etik audit } \\
\text { serta dilaksanakan oleh } \\
\text { orang orang yang }\end{array}$} & $\begin{array}{l}\text { Kualitas } \\
\text { perencanaan } \\
\text { audit }\end{array}$ & 13 & interval \\
\hline & & & $\begin{array}{l}\text { Kesesuaian } \\
\text { pelaksanaan } \\
\text { audit dengan } \\
\text { standar audit }\end{array}$ & 14 & Interval \\
\hline & & & Supervise & 15 & Interval \\
\hline
\end{tabular}


Rd. Susana Suspayati: Peran Akuntabilitas dan...

\begin{tabular}{|c|c|c|c|c|c|}
\hline No & Variabel & Konsep Variabel & Sub-Variabel & $\begin{array}{c}\text { No. } \\
\text { Pertanyaan }\end{array}$ & $\begin{array}{l}\text { Skala } \\
\text { Data }\end{array}$ \\
\hline & & \multirow{4}{*}{$\begin{array}{l}\text { kompeten dan } \\
\text { independen, sehingga } \\
\text { kemungkinan auditor } \\
\text { pada saat mengaudit } \\
\text { dapat menemukan } \\
\text { pelanggaran yang terjadi } \\
\text { dalam system } \\
\text { akuntansi/kinerja klient } \\
\text { dan melaporkannya. }\end{array}$} & audit & & \\
\hline & & & $\begin{array}{l}\text { Kualitas } \\
\text { laporan hasil } \\
\text { audit }\end{array}$ & 16 & Interval \\
\hline & & & $\begin{array}{l}\text { Keakuratan } \\
\text { temuan audit }\end{array}$ & 17 & Interval \\
\hline & & & $\begin{array}{l}\text { Tindak lanjut } \\
\text { hasil audit }\end{array}$ & $18-23$ & Interval \\
\hline \multirow[t]{3}{*}{4} & \multirow[t]{3}{*}{$\begin{array}{c}\text { Sikap Mental } \\
\text { Auditor }\end{array}$} & \multirow{3}{*}{$\begin{array}{l}\text { sikap merupakan suatu } \\
\text { keadaan siap mental, yang } \\
\text { dipelajari diorganisasi } \\
\text { menurut pengalaman, dan } \\
\text { yang menyebabkan } \\
\text { timbulnya pengaruh } \\
\text { khusus atas reaksi } \\
\text { seseorang terhadap } \\
\text { orang-orang, objek-objek, } \\
\text { dan situasi-situasi dengan } \\
\text { siapa ia berhubungan. }\end{array}$} & $\begin{array}{l}\text { Kepuasan } \\
\text { kerja }\end{array}$ & $24-26$ & Interval \\
\hline & & & $\begin{array}{l}\text { Keterlibatan } \\
\text { Kerja }\end{array}$ & $27-29$ & Interval \\
\hline & & & $\begin{array}{l}\text { Komitmen } \\
\text { Organisasi }\end{array}$ & $30-31$ & Interval \\
\hline
\end{tabular}

Sumber: Damayanti (2015), Hidayat (2015), Ichnatesya (2016). Dimodifikasi, 2018.

Metode Analisis Data
Ghozali (2014) mengelompokkan variabel moderator menjadi tiga kelompok seperti terlihat pada tabel di bawah ini.

Tabel 4. Jenis-jenis variabel moderator

\begin{tabular}{|c|c|c|}
\hline & $\begin{array}{c}\text { Berhubungan dengan } \\
\text { kriterior dana atau } \\
\text { prediktor }\end{array}$ & $\begin{array}{l}\text { Tidak berhubungan dengan } \\
\text { kriterior dan predicktor }\end{array}$ \\
\hline $\begin{array}{c}\text { Tidak berinteraksi dengan } \\
\text { predictor }\end{array}$ & $\begin{array}{c}1 \\
\begin{array}{c}\text { Intervening, Exogen, } \\
\text { Antesedent }\end{array} \\
\end{array}$ & $\begin{array}{c}2 \\
\text { Moderator } \\
\text { (Homologizer) }\end{array}$ \\
\hline $\begin{array}{l}\text { Berinteraksi dengan } \\
\text { prediktor }\end{array}$ & $\begin{array}{c}3 \\
\text { Moderator } \\
\text { (Quasi Moderator) }\end{array}$ & $\begin{array}{c}4 \\
\text { Moderator } \\
\text { (Pure Moderator) }\end{array}$ \\
\hline
\end{tabular}

Sumber : Ghozali (2014)

Berdasarkan Tabel 4 di atas, pertama pengelompokan berdasarkan hubungan dengan variabel kriterior (dependen), yaitu apakah variabel moderator berhubungan atau tidak berhubungan dengan variabel kriterior (dependen). Kedua, apakah variabel moderator berinteraksi dengan variabel prediktor (independen). Misalnya kita punya variabel kriterior (dependen) $Y$, variabel prediktor (independen) $\mathrm{X}$, dan variabel moderator Z. Berikut ini hubungan antara variabel kriterior, prediktor, dan moderator.

1. Jika variabel moderator $(Z)$ berhubungan dengan kriterior $(\mathrm{Y})$ dan atau prediktor $(\mathrm{X})$, tetapi variabel moderator (Z) tidak berinteraksi dengan prediktor seperti tabel kuadran 1, maka variabel $\mathrm{Z}$ bukan 
moderator tetapi merupakan intervening, exogen, anteseden atau prediktor.

2. Jika variabel pada tabel kuadran 2 mempengaruji kekuatan hubungan, tetapi tidak berinteraksi dengan variabel prediktor $(X)$ dan tidak berhubungan secara signifikan baik dengan prediktor $(X)$ maupun dengan variabel kriterior $(\mathrm{Y})$. dalam keadaan seperti ini, nilai residual atau eror merupakan fungsi moderator. Sehingga dengan membagi total sampel menjadi dua kelompok yang homogin dengan memperhatikan error variance akan meningkatkan nilai prediktif model. Jenis moderator seperti ini disebut dengan variabel homologizer.

3. Pada kuadran 3 , variabel moderator (Z) berhubungan dengan variabel kriterior $(\mathrm{Y})$ dan atau prediktor $(\mathrm{X})$ serta berinteraksi dengan variabel prediktor (X). Variabel moderator ( $\mathrm{Z})$ berfungsi sebagai variabel prediktor lainnya $(\mathrm{Y})$. Jenis moderator pada kuadran 3 disebut quasi moderator (moderator semu).

4. Pada kuadran 4, variabel moderator (Z) tidak berhubungan dengan variabel kriterior $(\mathrm{Y})$ dan prediktor $(\mathrm{X})$, tetapi berinteraksi dengan prediktor $(X)$. Variabel moderator (Z) tidak berfungsi sebagai variabel prediktor $(\mathrm{X})$ tetapi langsung berinteraksi dengan variabel prediktor lainnya $(\mathrm{X})$. Jenis moderasi pada kuadran 4 disebut pure moderator (moderator asli).

\section{Statistik Deskriptif}

Statistik deskriptif memberikan gambaran data dengan kriteria nilai rata-rata, standar deviasi, varian, maksimum, minimum, sum, range, kurtosis, dan skewness (Ghozali, 2011). Dengan statistik deskriptif variabelvariabel yang terdapat dalam penelitian akan dijelaskan. Selain itu, statistik deskriptif juga akan menyajikan ukuran-ukuran numerik yang penting bagi data sampel. Uji statistik deskriptif tersebut dilakukan dengan Program WarpPLS 6.0.
Untuk penelitian ini menggunakan alat analisis Structure Equation Modeling dengan Program WarpPLS 6.0. Variance atau component based Struktur Equation Modeling (WarpPLS) digunakan untuk menguji hipotesis. Alat analisis ini dipilih karena ada beberapa kelebihan yaitu didesain untuk dapat menyelesaikan persoalan seperti jumlah sampel yang kecil, data tidak terdistribusi normal secara multivariate, adanya missing value, dan adanya problem multikolinieritas antar variabel eksogen (Ghozali, 2011).

Menurut Ghozali (2014) menyatakan bahwa tahapan model analisis menggunakan WarpPLS 6.0 setidaknya harus melewati lima proses tahapan yaitu sebagai berikut:

1. Konseptualisasi model

Tahap ini mendefinisikan secara konseptual konstruk yang diteliti dan menentukan dimensionalitas. Arah hubungan kausalitas antar konstruk yang dihipotesiskan ditentukan dengan indikator pembentuk konstruk laten harus ditentukan apakah berbentuk reflective ataukah formative. Indikator penelitian ini pembentuk konstruk laten berbentuk formative. Konstruk dengan indikator formative mengasumsikan bahwa setiap indikatornya mendefinisikan atau menjelaskan karakteristik domain konstruknya.

2. Menentukan metode analisis algorithm Metode analisis algorithm digunakan untuk estimasi model. Dalam WarpPLS 6.0 ada empat pilihan metode analisis algorithm yaitu WarpPLS Regression, WarpPLS Regression, PLS Regression dan Robust Path Analysis. Setelah menentukan metode analisis algorithm yang digunakan, kemudian menentukan berapa jumlah sampel yang harus dipenuhi. Analisis algorithm yang digunakan adalah $P L S$ Regression dengan number of data resamples yang digunakan sebesar 80 .

3. Menentukan metode resampling
Untuk
melakukan
resampling menggunakan metode bootstrapping dan 
jackknifing. Metode bootstrapping menggunakan seluruh sampel asli untuk melakukan resampling kembali. Sedangkan metode jackknifing hanya menggunakan subsampel dari sampel asli yang dikelompokkan ke dalam grup untuk melakukan resampling kembali.

Dalam penelitian ini metode resampling yang digunakan adalah jackknifing. Metode resampling jackknifing memiliki kelebihan yaitu jackknifing memiliki parameter yang lebih stabil dalam estimasi dengan analisis yang menyesatkan. Köck dan Paramythis (2011) metode Jackknifing juga dianggap merupakan alat analisis yang lebih baik daripada bootstrapping untuk mengatasi masalah yang terkait dengan kehadiran outlier karena kesalahan dalam pengumpulan data.

4. Pengembangan Diagram Alur (Path Diagram).

Atas dasar model teoritik maka sebuah diagram alur dapat dikembangkan pada gambar 3.1 sebagai berikut:

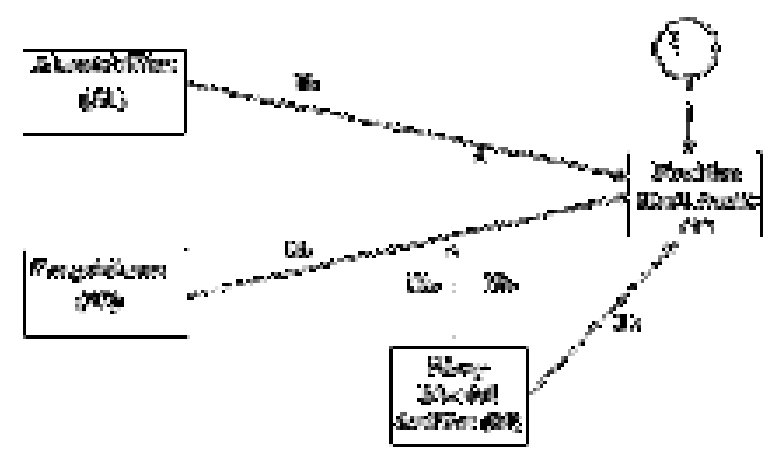

Gambar 2. Moderating Analysis - Model Specification

Sumber : data olah tahun (2018)

Ghozali (2014), Konstruk-konstruk yang dibangun dalam Gambar 2. dapat dibedakan dalam dua kelompok konstruk yaitu konstruk exogen dan kontruk endogen yang diuraikan berikut ini:

1. Konstruk Exogen (Exogenous Construct). Konstruk exogen dikenal sebagai source variable atau independent variable yang tidak diprediksi oleh variabel lain dalam model. Pada gambar di atas terdapat dua konstruk eksogen yaitu; akuntabilitas dan pengetahuan.

2. Konstruk Endogen (Endogen Construct). Konstruk Endogen adalah faktor-faktor yang diprediksi oleh satu atau beberapa konstruk. Konstruk Endogen dapat diprediksi satu atau beberapa konstruk endogen lainnya, tetapi konstruk eksogen hanya dapat berhubungan kausal dengan konstruk endogen. Gambar 3.1. menunjukkan konstruk endogen dalam kode tersebut adalah, kualitas hasil audit. Adapun konversi diagram alur ke dalam persamaan, adalah sebagai berikut:

Konversi diagram alur ke dalam persamaan (Pengujian Hipotesis 1, Hipotesis 2, dan Hipotesis 3)

Persamaan jalur yang dibangun adalah sebagai berikut:

Persamaan Struktur I:

N1: $\beta_{0}+\beta_{1} \zeta_{1}+\beta_{2} \zeta_{2}+\beta_{3} \zeta_{3} \zeta+\beta_{4} \zeta_{1}{ }^{*} M+\beta_{5} \zeta 2 * M+$ $\zeta \quad(1)$

Dalam hal ini:

$\zeta_{1} \quad$ : Akuntanbilitas

$\zeta_{2}$ : Pengetahuan

$\zeta_{3} / \mathrm{M}$ : Sikap Mental Auditor

$\mathrm{N} \quad$ : Kualitas hasil audit

BO : Konstanta

$\beta_{1.33}$ : Slope

$\zeta 1-\zeta 3$ : Residual

\section{PENGUJIAN HIPOTESIS DAN HASIL STATISTIK} Hasil Pengujian Full Model

Penelitian ini menggunakan data primer. Variabel yang digunakan merupakan variabel yang memiliki satu konstruk formatif. Tujuan penelitian ini adalah untuk menguji pengaruh akuntabilitas terhadap kualitas kualitas hasil audit, pengaruh pengetahuan terhadap kualitas hasil audit, pengaruh sikap mental auditor terhadap kualitas hasil audit, pengaruh akuntabilitas terhadap kualitas hasil 
audit dengan moderasi sikap mental auditor, pengaruh pengetahuan terhadap kualitas hasil audit dengan moderasi sikap mental. Analisis yang dilakukan bertujuan untuk mengetahui hubungan variabel eksogen (akuntabilitas dan pengetahuan) dengan variabel endogen (kualitas hasil audit). Terdapat hipotesis hubungan yang akan diuji apakah ada pengaruh antara akuntabilitas $\left(X_{1}\right)$ dan pengetahuan $\left(\mathrm{X}_{2}\right)$ dengan kualitas hasil audit (Y). Untuk mengujinya digunakan program WarpPLS 6.0. Hasil pengolahan dengan program tersebut dapat dilihat pada gambar berikut.

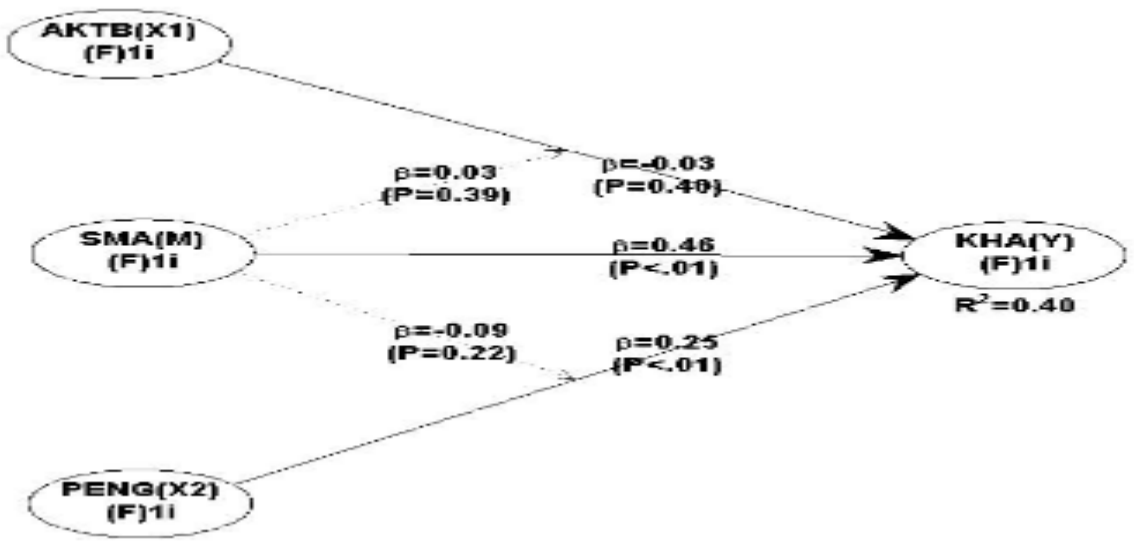

Gambar 3. Full Model Mediator

Lebih jelas, hasil analisis ini dapat dilihat dalam beberapa tabel Model Fit and Quality Indices sebagai berikut.

Tabel 5. Model Fit and Quality Indices

\section{Model Fit and Quality Indices}

Average path coefficient $(\mathrm{APC})=0.171, \mathrm{P}=0.028$

Average R-squared (ARS) $=0.398, P<0.001$

Average adjusted R-squared (AARS) $=0.357, P<0.001$

Average block VIF (AVIF) $=1.502$, acceptable if $<=5$, ideally $<=3.3$

Average full collinearity $\operatorname{VIF}(\mathrm{AFVIF})=1.464$, acceptable if $<=5$, ideally $<=3.3$

Tenenhaus GoF (GoF)=0.631, small >=0.1, medium $>=0.25$, large $>=0.36$

\begin{tabular}{c|c|c}
\hline Jalur & Path Coeficient $(\boldsymbol{\beta})$ & P Value \\
\hline AKTB $\rightarrow$ KHA & -0.03 & 0.40 \\
\hline PENG $\rightarrow$ KHA & 0.25 & $<0.01$ \\
\hline SMA $\rightarrow$ KHA & 0.46 & $<0.01$ \\
\hline SMA * AKTB $\rightarrow$ KHA & 0.03 & 0.39 \\
\hline SMA * PENG $\rightarrow$ KHA & -0.09 & 0.22 \\
\hline
\end{tabular}

Sumber: Data diolah (2018).

Tabel 6. Latent Variable Coefficients

\begin{tabular}{c|c}
\hline \multicolumn{2}{c}{ Latent Variable Coefficients } \\
\hline KHA & Nilai Kontribusi \\
\hline R-squared coefficients & 0.398 \\
\hline Q-squared coefficients & 0.357 \\
\hline
\end{tabular}


Rd. Susana Suspayati: Peran Akuntabilitas dan...

\begin{tabular}{c|c}
\hline Full collinearity VIFs & 1.000 \\
\hline
\end{tabular}

Sumber: Data diolah (2018).

Tabel 7. Ringkasan Hasil Pengujian Hipotesis dan Model Moderasi

\begin{tabular}{|c|c|c|c|c|}
\hline $\begin{array}{c}\text { Hubungan Antar } \\
\text { Variabel }\end{array}$ & $\begin{array}{c}\text { Nilai } \\
\text { Koefisoen } \\
(\beta)\end{array}$ & $\begin{array}{l}\text { Nilai } P \\
(\leq 0.05)\end{array}$ & $\mathbf{H}_{\mathbf{a}}$ & Kesimpulan \\
\hline $\begin{array}{c}\text { Hipotesis 1: } \\
\text { Akuntabilitas terhadap } \\
\text { Kualitas Hasil Audit } \\
(\text { AKTB } \rightarrow \text { KHA) }\end{array}$ & -0.03 & 0.40 & Ditolak & $\begin{array}{c}\text { Tidak ada } \\
\text { pengaruh dan } \\
\text { tidak signifikan }\end{array}$ \\
\hline $\begin{array}{c}\text { Hipotesis 2: } \\
\text { Pengetahuan terhadap } \\
\text { Kualitas Hasil Audit } \\
\text { (PENG } \rightarrow \text { KHA) }\end{array}$ & 0.25 & $<0.01$ & Diterima & $\begin{array}{c}\text { Berpengaruh } \\
\text { Positif dan } \\
\text { Signifikan }\end{array}$ \\
\hline $\begin{array}{c}\text { Hipotesis } 3: \\
\text { Sikap Mental Auditor (M) } \\
\text { terhadap Kualitas Hasil Audit } \\
(\mathrm{SMA} \rightarrow \mathrm{KHA})\end{array}$ & 0.46 & $<0.01$ & Diterima & $\begin{array}{l}\text { Berpengaruh } \\
\text { Positif dan } \\
\text { Signifikan }\end{array}$ \\
\hline $\begin{array}{c}\text { Hipotesis } 4: \\
\text { Akuntabilitas dengan } \\
\text { moderasi Sikap Mental } \\
\text { Auditor terhadap Kualitas } \\
\text { Hasil Audit } \\
\left(\mathrm{SMA}^{*} \text { AKTB } \rightarrow \text { KHA }\right)\end{array}$ & 0.03 & 0.39 & Ditolak & $\begin{array}{c}\text { Tidak ada } \\
\text { pemoderasi } \\
\text { akuntabilitas } \\
\text { terhadap KHA }\end{array}$ \\
\hline $\begin{array}{c}\text { Hipotesis } 5 \text { : } \\
\text { Pengetahuan dengan } \\
\text { moderasi Sikap Mental } \\
\text { Auditor terhadap Kualitas } \\
\text { Hasil Audit } \\
\text { (SMA*PENG } \rightarrow \text { KHA) }\end{array}$ & -0.09 & 0.22 & Ditolak & $\begin{array}{c}\text { Tidak ada } \\
\text { pemoderasi } \\
\text { pengetahuan } \\
\text { terhadap KHA }\end{array}$ \\
\hline
\end{tabular}

Hasil uji terhadap koefisien parameter antara akuntabilitas terhadap kualitas hasil audit menunjukkan tidak ada pengaruh dengan nilai $P$ value sebesar 0,500 dan signifikan pada $\alpha=5 \%$. Nilai T-Statistic tersebut berada jauh di atas nilai kritis $(0,05)$. Hal yang berbeda terjadi pada hubungan variabel pengetahuan, sikap mental auditor dengan kualitas hasil audit, menunjukan nilai probabilitas (PValue) tersebut berada jauh di bawah nilai kritis $(0,05)$. Sehingga hanya pengetahuan dan sikap mental auditor yang berpengaruh positif dan signifikan terhadap kualitas hasil audit.

Pembahasan Hasil Penelitian

Akuntabilitas terhadap Kualitas Hasil Audit dan Akuntabilitas dengan Moderasi Sikap Mental Auditor terhadap Kualitas Hasil Audit

Berdasarkan hasil penelitian di atas, Akuntabilitas tidak berpengaruh terhadap Kualitas Hasil Audit. Hal ini terjadi dikarenakan 
berdasarkan standar umum audit, dikatakan bahwa auditor harus melaksanakan tugasnya dengan cermat dan seksama karena kecermatan dan keseksamaan merupakan tanggung jawab auditor. Jadi akuntabilitas tidak berpengaruh karena nara sumber yang dijadikan sebagai objek penelitian dalam melaksanakan tugasnya kurang cermat dan kurang seksama. Hal itu disebabkan karena auditor masih minim pengalaman.

Penelitian ini tidak sejalan dengan penelitian Saripudin (2012), Mardisar dan Sari (2007), Ardini (2010), Hidayat (2015), Putu, dkk (2014) yang menyatakan bahwa akuntabilitas memiliki pengaruh terhadap kualitas hasil audit. Namun penelitian ini didukung dengan hasil penelitian Arisanti, dkk (2013), dan Kadek, dkk (2015) yang menyatakan bahwa akuntabilitas tidak mempunyai pengaruh signifikan positif terhadap kualitas hasil audit.

Berdasarkan teori yang diungkapkan oleh Mardiasmo (2002) bahwa akuntabilitas publik adalah pemberian informasi dan pernyataan atas aktivitas dan kinerja finansial pemerintah kepada pihak-pihak yang berkepentingan dengan laporan tersebut. Pemerintah, baik pusat maupun daerah, harus bisa menjadi subyek pemberi informasi dalam rangka pemenuhan hak- hak publik. Seorang auditor yang memiliki akuntabilitas tinggi akan bertanggungjawab penuh terhadap pekerjaannya sehingga kualitas audit yang dihasilkan pun akan semakin baik, sedangkan hasil penelitian menunjukkan bahwa akuntabilitas tidak berpengaruh positif terhadap kualitas hasil audit. Hal ini berarti bahwa hasil penelitian ini tidak sesuai dengan hipotesis yang dikemukakan sebelum dilakukannya penelitian. Kondisi itu terjadi karena kurang efektif dan efisiennya pelayanan jasa audit terhadap kualitas hasil audit yang disampaikan.

Berdasarkan hasil penelitian di atas, tidak ada pemoderasi akuntabilitas terhadap kualitas hasil audit. Hal ini disebabkan karena sikap mental auditor secara langsung berpengaruh positif dan signifikan terhadap kualitas hasil audit. Saat ini belum ada penelitian yang meneliti tentang pengaruh akuntabilitas dengan moderasi sikap mental auditor terhadap kualitas hasil auditor.

Pengetahuan terhadap Kualitas Hasil Audit dan Pengetahuan dengan Moderasi Sikap Mental Auditor terhadap Kualitas Hasil Audit

Berdasarkan hasil penelitian di atas, pengetahuan berpengaruh positif dan signifikan terhadap kualitas hasil audit yang artinya saat pengetahuan yang dimiliki auditor semakin tinggi maka kualitas hasil audit akan lebih baik. Hal ini didukung oleh Kantor Akuntan Publik yang sering mengadakan pelatihan kepada auditornya untuk menunjang kualitas hasil auditnya, selain itu pendidikan yang dimiliki auditor serta keahlian dan keterampilan kerja yang dimiliki auditor sudah sangat baik pada ketiga KAP tersebut.

Hasil penelitian ini sesuai dengan hasil penelitian yang dilakukan oleh Mardisar dan Sari (2007), Ichnatesya (2016), Damayanti (2015), Febri (2017), Purnamasari dan Erna (2013), Putu, dkk (2014), dan Ali, dkk (2017) menyatakan bahwa pengetahuan memiliki pengaruh signifikan terhadap kualitas audit.

Berdasarkan Permen PAN Nomor PER/05/M.PAN/03/2008 tentang Standar Audit Aparat Pengawasan Intern Pemerintah (APIP) menjelaskan seorang auditor harus memiliki keahlian tentang standar audit, kebijakan, prosedur dan praktik-praktik audit. Untuk itu, auditor harus senantiasa meningkatkan pengetahuan audit yang merupakan dasar utama bagi auditor untuk melaksanakan tugas audit secara profesional sehingga hasil audit dapat memiliki mutu yang sesuai dengan standar yang ditetapkan.

Pengetahuan audit yang harus dimiliki bagi seorang auditor tidak hanya berupa pengetahuan secara sempit atas konsep audit tetapi juga harus memiliki pengetahuan secara komprehensif yang meliputi pengetahuan atas 
bisnis proses audit, akuntansi sektor publik, administrasi pemerintah dan ilmu lainnya terkait dengan akuntabilitas audit. Disamping itu, auditor yang melaksanakan audit juga diharuskan memiliki pengetahuan yang memadai terkait kecurangan antara lain berupa pengetahuan mengenai money laundry, tindak pidana korupsi, hukum/peraturan terkait bukti pengadilan, cybercrime, dan ketentuan lain terkait pelaksanaan audit.

Adanya pengaruh positif dan signifikan pengetahuan terhaadap kualitas hasil audit memiliki dampak yang berarti yaitu dapat memberikan kepercayaan yang tinggi baik kepada pimpinan maupun audit bahwa hasil audit yang telah dilakukan merupakan hasil yang dapat diandalkan, dapat memberikan rekomendasi yang tepat dan bernilai tambah untuk perbaikan proses bisnis audit, membantu pelaksanaan audit secara efektif dan efisien terutama terhadap proses bisnis audit memiliki sifat dinamis terhadap perubahan kebijakan pimpinan atau peraturan tertentu, dan meningkatkan nilai kredibilitas instansi audit secara keseluruhan dengan kemampuan profesional para auditor yang kompetitif.

Berdasarkan hasil penelitian di atas, tidak ada pemoderasi pengetahuan terhadap kualitas hasil audit. Hal ini disebabkan karena sikap mental auditor secara langsung berpengaruh positif dan signifikan terhadap kualitas hasil audit. Saat ini belum ada penelitian yang meneliti tentang pengaruh pengetahuan dengan moderasi sikap mental auditor terhadap kualitas hasil auditor.

\section{Sikap Mental Auditor terhadap Kualitas Hasil Audit}

Berdasarkan hasil penelitian di atas, sikap mental auditor berpengaruh positif dan signifikan terhadap kualitas hasil audit artinya saat sikap mental auditor yang dimiliki auditor baik maka kualitas hasil audit akan lebih baik. Hal ini dapat dilihat dari kepuasan kerja, keterlibatan kerja dan komitmen organisasi yang dimiliki oleh auditor. Penelitian ini tidak sejalan dengan penelitian Alim, dkk (2007), yang menyatakan bahwa sikap auditor tidak berpengaruh signifikan terhadap kualitas hasil audit. Namun penelitian ini didukung dengan hasil penelitian yang dilakukan oleh Damayanti (2015) yang menyatakan bahwa adanya pengaruh yang signifikan antara pengetahuan dan sikap auditor terhadap kualitas hasil audit.

Dalam menjalankan aktivitas independennya, seorang auditor internal dituntut untuk memiliki sikap profesional. Menurut Robbins (2003) definisi sikap adalah pernyataan atau pertimbangan evaluative, baik yang menguntungkan atau tidak menguntungkan mengenai objek, orang atau pariwisata. Sikap lahir dari suatu proses-proses yang kompleks seperti pengamatan, motivasi, dan emosi. Nilai sikap auditor sangat diperlukan untuk mendukung hasil kerjanya agar dapat dipercaya publik.

\section{PENUTUP}

\section{Simpulan}

1. Berdasarkan pada hasil penelitian serta pengujian hipotesis dapat ditarik kesimpulan penelitian sebagai berikut:

2. Tidak ada pengaruh yang signifikan antara akuntabilitas terhadap kualitas hasil audit. Kondisi itu terjadi karena nara sumber yang dijadikan sebagai objek penelitian dalam melaksanakan tugasnya kurang cermat dan kurang seksama. Hal itu disebabkan karena auditor masih minum pengalaman.

3. Tidak ada pengaruh pemoderasi antara akuntabilitas dengan moderasi sikap mental auditor terhadap kualitas hasil audit. Hal ini disebabkan karena sikap mental auditor secara langsung berpengaruh positif dan signifikan terhadap kualitas hasil audit.

4. Ada pengaruh yang signifikan positif antara pengetahuan terhadap kualitas hasil audit. Semakin tinggi pengetahuan yang dimiliki oleh auditor maka semakin tinggi pula kualitas hasil auditornya. Hal ini didukung oleh Kantor Akuntan Publik yang sering 
mengadakan pelatihan kepada auditornya untuk menunjang kualitas hasil auditnya, selain itu pendidikan yang dimiliki auditor serta keahlian dan keterampilan kerja yang dimiliki auditor sudah sangat baik pada ketiga KAP tersebut.

5. Tidak ada pemoderasi antara pengetahuan dengan moderasi sikap mental auditor terhadap kualitas hasil audit. Hal ini disebabkan karena sikap mental auditor secara langsung berpengaruh positif dan signifikan terhadap kualitas hasil audit.

6. Ada pengaruh yang signifikan positif antara sikap mental auditor terhadap kualitas hasil audit. Semakin tinggi sikap mental auditor yang dimiliki oleh auditor maka semakin tinggi pula kualitas hasil auditornya.

\section{Saran}

Penelitian ini memiliki keterbatasan, diantaranya adalah: bahwa penggunaan variabel moderating memungkinkan menggunakan variabel intervening dan keterbatasan waktu peneliti tidak melakukan botstrapping. Selain itu, penelitian ini hanya menggunakan tiga Kantor Akuntan Publik. Saran yang dapat diberikan untuk penelitian selanjutnya adalah:

1. Penambahan variabel lain, misalnya dengan menambahkan variabel gender yang mungkin dapat mempengaruhi kualitas hasil audit.

2. Penambahan jumlah Kantor Akuntan Publik agar dapat memberikan hasil penelitian dalam scope yang lebih luas.

3. Penggunaan variabel intervening dalam model penelitian.

4. Objek penelitian lebih terfokus pada auditor senior keatas.

5. Melakukan bot strapping dalam pengolahan data.

\section{REFERENSI}

Ali, Muhammad I., et al. (2017). Pengaruh Pengetahuan Audit, Independensi Dan
Pengalaman Auditor Terhadap Kualitas Hasil Audit Investigasi Pada Auditor Inspektorat Jenderal Kementerian Keuangan. Jurnal IImiah WIDYA Ekonomika Volume 1 Nomor 3 Juli 2017, hlm. 1-8.

Alim. M. N., et al. (2007). Pengaruh Kompetensi dan Independensi terhadap Kualitas Audit dengan Etika Auditor sebagai Variabel Moderasi. SNA $X$ Makassar. AUEP-08, hlm., 1-26.

Ardini, L. (2010). Pengaruh Kompetensi, Indepedensi, Akuntabilitas dan Motivasi terhadap Kualitas Audit. Majalah Ekonomi No 3.

Arisanti, D., et al. (2013). Pengaruh Independensi, Pengalaman Kerja, Due Profesional Care, Akuntabilitas dan Kompetensi Terhadap Kualitas Audit. Jurnal Akuntansi Universitas Bung Hatta, Vol. 2 No. 1 Tahun 2013, hlm. 113.

Badan Pemeriksa Keuangan Republik Indonesia. (2007). Peraturan Badan Pemeriksa Keuangan Republik Indonesia No. 01 Tahun 2007 Tentang Standar Pemeriksaan Keuangan Negara. Jakarta: BPK RI.

Damayanti, Tesalonika R. (2015). Pengaruh time budget pressure, pengetahuan, pengalaman dan sikap auditor terhadap kinerja auditor internal pada inspektorat Jenderal. Skripsi. Depok: Universitas Pancasila.

Departemen Agama RI. (2008). Al-Qur'an dan terjemahannya. Bandung: Diponegoro.

Elfarini, Eunike C. (2007). Pengaruh Kompetensi dan Independensi Auditor terhadap Kualitas Audit. Skripsi. Semarang: Universitas Negeri Semarang.

Febri, Muhammad H. (2017). Pengaruh Independensi, Integritas, Pengetahuan, Pengalaman Kerja Dan Akuntabilitas Terhadap Kualitas Audit (Studi Empiris pada Auditor BPKP Perwakilan Jawa 
Tengah). Skripsi. Surakarta: Universitas Muhammadiyah Surakarta.

Festinger, L. (1957). A Theory of Cognitive Dissonance. California: Stanford University Press.

Ghozali, I. dan Chariri. A. (2007). Teori Akuntansi. Semarang: Badan Penerbit Universitas Diponegoro.

Ghozali, I. (2011). Aplikasi Analisis Multivariante dengan program IBM SPSS 19. Edisi kelima.

(2013). Aplikasi Analisis Multivariante dengan program SPSS.

2014. Structural Equation Modeling Metode Alternatif Dengan Partial Least Squares (PLS). Edisi 4.

Harhinto, T. (2004). Pengaruh Keahlian dan Independensi Terhadap Kualitas Audit Studi Empiris Pada KAP di Jawa Timur. Semarang. Tesis. Semarang: Universitas Diponegoro.

Hidayat, S. (2015). Pengaruh Kompetensi, Independensi Akuntabilitas dan Etika Auditor Terhadap Kualitas Hasil. Tesis. Jakarta: Universitas Pancasila.

Ichnatesya, Afika S. (2016). Pengaruh Pengalaman, Pengetahuan, Etika, dan Motivasi Terhadap Kualitas Audit (Studi Empiris Pada KAP di Jakarta Selatan). Skripsi. Depok: Universitas Pancasila.

Irawan, I. (2018). Teori Stakeholder. Tersedia di:

https://irwanirawan.net/2009/06/08/te ori-stakeholder/ (Diakses pada 5 Mei 2018).

Kadek, Ayu P., et al. (2015). Pengaruh Kompetensi, Independensi, Obyektivitas, Integritas Dan Akuntabilitas Terhadap Kualitas Audit Di Pemerintah Daerah (Studi Empiris Pada 5 Kantor Inspektorat Provinsi Bali). eJournal S1 Ak Universitas Pendidikan Ganesha Jurusan Akuntansi Program S1. Vol 3 No. 1 Tahun 2015.
LAN. (2011). Instrument Akuntabilitas Bidang Auditif. Jakarta: LAN

Mardiasmo. (2009). Akuntansi Sektor Publik. Yogyakarta: Penerbit Andi.

Mardisar, D. dan Sari, R. N. (2007). Pengaruh Akuntabilitas dan Pengetahuan terhadap Kualitas Hasil Kerja Auditor. SNA X Makassar.

Mulyanto. H, dan Wulandari, A. (2010). Penelitian: Metode dan Analisis. Semarang: Penerbit CV Agung.

Murwaningsari, E. (2009). Hubungan Corporate Governance, Corporate Social Responsibilities dan Corporate Financial Performance Dalam Satu. Jurnal Akuntansi dan Keuangan. Vol. 11 No. 1 Tahun 2009, hlm. 30-41.

Peraturan Menteri Negara Pendayagunaan Aparatur Negara Nomor: PER/05/M.PAN/03/2008 tentang Standar Audit Aparat Pengawasan Intern Pemerintah.

Purnamasari, D. dan Hernawati, E. (2013). Pengaruh Etika Auditor, Pengalaman, Pengetahuan dan Perilaku Disfungsional Terhadap Kualitas Audit. Jurnal Neo-Bis Volume 7, No.2, Desember 2013.

Putu, Ni Luh Tri Angga W., et al. (2014). Pengaruh Pengetahuan, Pengalaman Kerja Audit, Dan Akuntabilitas Terhadap Kualitas Hasil Kerja Auditor Internal. $e$ Journal S1 Ak Universitas Pendidikan Ganesha Jurusan Akuntansi Program S1. Volume 2 No. 1 Tahun 2014.

Robbins, Stephen P. (2003). Organizational Behavior. New Jersey: Prentice Hall.

Saripudin, Herawaty. N, dan Rahayu. (2012). Pengaruh Independensi, Pengalaman, Due Profesional Care, dan Akuntabilitas Terhadap Kualitas Audit, e-Jurnal BINAR Akuntansi Vil.1 No.1, September 2012, ISSN 2302-1522.

Sarwono, S. (2009). Psikologi Sosial. Jakarta: Salemba Himanika.

Siregar, S. (2010). Statistik Deskriptif untuk Penelitian: Dilengkapi Perhitungsn 
Manual dan Aplikasi SPSS Versi 17. terhadap Kinerja Auditor Kehutanan Jakarta: RajaGrafindo Persada.

Standar Profesional Akuntan Publik pada Itjen Departemen Kehutanan. Sugiyono. (2014). Statistik Untuk Penelitian. Bandung: CV Alfabeta.

Wahyuni, H. (2007). Pengaruh Kompetensi, Perilaku dan Budaya Organisasi 
